\title{
AN ANALYSIS OF COMMITMENT FACTORS DEPENDING ON GENERATION AND PART-TIME WORKING IN SELECTED GROUPS OF EMPLOYEES IN HUNGARY
}

In our empirical research based upon 661 respondents we analyzed the factors of employee commitment in some of typical groups of employees. We examined the correlations among the organizational, professional and deliberate commitment factors in the groups of the career beginners of Generation Y, remotely employed teleworkers and the re-employed. In our study we took account of both forms of employment and the effects of generational differences as well. It can be demonstrated that, on the one hand, deliberate commitment has an organizational role and on the other hand, according to the nature of employment and characteristics of generation cohorts, the above employing organizations can create motivational systems for their employees.

Keywords: employee commitment; organizational commitment; professional commitment; deliberate commitment; part-time workers; generation cohorts

DOI: $10.15611 /$ aoe.2014.2.06

\section{INTRODUCTION}

A high level of employee organizational commitment has several advantages for the organization. We can find numerous research on the attitudes towards the organization which are based on commitment, such as a decrease in workplace absenteeism, organizational citizenship behaviour (OCB) increase and falling fluctuation (Mathieu and Zajac 1990, Meyer et al., 2002; Ng and Feldman 2011).The evolution of the concept of commitment dates back several years. There is no agreement on the accurate concept of commitment, thus the factors which characterize this attitude are also ambiguous. According to Becker's one-side-bet theory (1960), commitment is one-dimensional and as an attitude it is based on evaluating

\footnotetext{
* Department of Economic Development, Office for National Economic Planning, Hungary

** Department of Management and Corporate Economics, Budapest University of Technology and Economics, Hungary
} 
the reasons that would cause a person to leave the organization. Later, Angle and Perry (1981) defined the value commitment and the commitment to stay, where they determined the demand of employees for identification with the organizational goals and their intention of staying in the organization. Meyer and Allen (1991) defined commitment in an even more complex way: in their three-component model of commitment they distinguished the affective, the normative and the continuance commitment factors. Meanwhile, some researchers like Wallace (1995), Rothwell and Arnold (2007) analyzed the impact of the occupational and the professional commitment in the workplace. Professional commitment has several consequences which determine the individual's organizational behaviour. To characterize the employee commitment, besides the three components (factors) of organizational commitment, we suggest that in our integrated model the so-called deliberate commitment should also have a place. Considering the above, the essence of the concept of commitment does not change and it remains complex enough to analyze it from the aspect of drivers of organizational behaviour. The resulting employee commitment model was used first to try to describe more accurately the effect of the age and the form of employment on commitment in some selected groups of employees, and on the other hand, we measured the correlations between the commitment factors, whether these are independent of the employee groups. The strengths of the commitment factors were investigated in the group of Gen Y, the previously unemployed and the teleworkers. The examination of commitment is an especially important aspect of young career starters, because there is a radical difference between the attitudes of the employees in Gen Y and the older generations, which for example makes more difficult the processes of the 'workplace inset' and the creation of a balanced organizational culture, while the companies have fewer opportunities to acquire new young talent due to the demographic trends in developed countries. The commitment of a group of previously unemployed can also be interesting, since long-term unemployment causes harmful consequences for the individual's psyche, and becomes a major challenge for companies to reintegrate them back to work. In contrast with the previous two employee groups, teleworkers are not considered as a disadvantaged group in the labour market, but specific motivational tools should be required due to their specific form of employment, because the absence of a physical presence develops another type of commitment in relation to typical employees. The results of the study are valid for the characteristics of the Hungarian labour market. 


\section{THEORETICAL BACKGROUND}

\subsection{Integrating the deliberate commitment factor with professional and organizational commitments}

While analyzing organizational commitment, three commitment factors are determined. Affective commitment is characterized by the employees' emotional engagement towards their organizations and colleagues. In the long-term, this attachment motivates them to identify themselves with the organization (Allen and Meyer 1990, Meyer and Allen 1997). In most cases affective commitment expresses the positive emotions attached by employees to organizations, also in this attitude the role of the expression of individual desires is the highest. This behaviour has no other motivator, only the internal driver. Therefore the management must recognize individual preferences to increase affective commitment, but influencing organizational commitment is the easiest via this factor. The continuance commitment was first defined by Becker (1960). This behaviour is characterized by the fact that, considering their expenditure, the observed employees stay as members of the organization as long as it is worthwhile. This means that it is a calculative-based attitude and the commitment exists until an alternative employment possibility is worth more (Ilieva 1999). In the interpretation of continuance commitment there are exactly quantifiable costs (e.g. changes in the scale of wages in the old and new job relation), and the other part of the costs depends on individual preferences and considerations (e.g. the value of friendships and business contacts, some of them are lost during job changing). Therefore continuance commitment does not mean a real insistence, but rather explains employees' intentions in some cases. So it is not clear whether a low or a high level of continuance commitment represents real value for organizations. Normative commitment means that the employee considers being a member of the employing organization as a moral obligation (Allen and Meyer 1990). The internal sense of duty in the normative commitment may stem from the fact that the organization has developed employees' competences over a long period of time at their own cost, facilitated a reasonable career path or used alternative employment methodologies to avoid redundancy. Such activities of enterprises contribute to the development of a high degree of normative commitment after a relatively long time.

Even the three-component model of the organizational commitment by Meyer and Allen (1991), which is also widely used in occupational 
psychology and in management research, does not contain all the factors which influence employees' loyalty to their workplace. One of them is occupational commitment, for instance, which is based on organizational citizenship behaviour (OCB). It involves all activities carried out for the organization which are neither set out in job descriptions nor remunerated officially, but increase organizational effectiveness (Organ 1988). This is apparent for policemen (Chen and Kao 2012) and also for university lecturers (Lawrence et al. 2011). According to the social exchange theory, the main condition of OCB is the fact that employees recognize their own roles in the organization and regarding their organizational well-being they decide to support their place of work as an internal obligation (Eisenberger et al. 1986). Instead of formal management tools, the appearance of OCB can only be supported directly with applying, for instance, the reinforcement theory of motivation (Bettencourt et al. 2001). However, against the above background, OCB, in relation with the normative nature of organizational commitment, does not demonstrate more frequent occurrence in certain occupations. In other words, OCB can appear in such cases where the affective, the continuance and the normative commitment factors are not maximal.

The contradiction above can be solved by the concept of professional commitment. Furthermore, employee commitment means organizational and professional commitments together. Employees' professional commitment results in identification with their profession, high participation and devotion to their work and acceptance of the discipline and purposes of the Code of Ethics (Sorensen and Sorensen 1974). Essentially, this results in independence in the course of knowledge application, improves loyalty towards a part of the current profession and also the identification with work, furthermore it allows the ethical application of knowledge in the sense of social responsibility (Kozlowski and Hults 1986). In particular, health institutions, research institutions, designers, accountants and lawyers are characterized by a high level of professional commitment (Wallace 1995).

The concept of employee commitment is necessary to allow us to analyze organizational and professional commitments taken together. Instead of commitment models, our analysis is based upon commitment factors or components. Furthermore, employee commitment is defined by a special ratio of five commitment factors: the affective, the continuance and the normative factors from Meyer and Allen's three-component organizational commitment model, and additionally, the professional and the so-called 'deliberate' commitment factors as well. The organizational commitment 
(affective, continuous and normative) factors, in addition to professional commitment and deliberate factors, can be interpreted in the employee commitment model. The resulting commitment model is suited to identify employees' commitment profiles more accurately in some specific employee groups (Krajcsák 2014). The employee commitment model can provide a more detailed structure of certain variables, such as the effects of generational cohorts or the effects of employment form. Considering the different explanations of the concept of commitment, it is assumed that there is also a factor called the 'deliberate' commitment factor, which is not yet defined by the models of organizational commitment. This attitude is a result of the willful and deliberate action of an employee pretending commitment to the employing organization for his/her own good against other employees. Such behaviour can be a result of, for instance, the growing fear of being made redundant due to the economic crisis. In the three-component organizational commitment model by Meyer and Allen (1991), the deliberate and the continuance commitment are related to each other in the aspect of the resulting calculative actions and improving neither individual performance nor OCB (Meyer et al. 2002). While the continuously committed employee possesses a non-transformable investment in his/her work, the invested and acquired assets and benefits cannot be profitable for him/her in any other way, or not as much that it would be worth changing jobs (Reichers 1985, Meyer and Allen 1997), the deliberately committed employee is in a difficult situation with no chance of new employment possibilities, and so to avoid being made redundant he/she chooses to pretend more committed behaviour than the working conditions and his/her individual preferences would require. Consequently, it is assumed that similarly to continuance commitment (e.g. Sinclair et al. 2005, Tolentino 2013), the deliberate commitment attitude does not influence individual work performance and quality of work, but does improve work attendance and attenuates turnover intention.

\subsection{Selected groups of employees}

The commitment attitude can be analyzed in relation to several individual and organizational factors. Our research was based on whether the employee was involved in any disadvantaged groups from the aspect of the labour market (career beginners of Generation Y and the re-employed) or any other groups which require special motivational tools (teleworkers). The first group is the group of career beginners of Generation Y. In accordance with 
the Act CXXIII of 2004 on the Employment of Career Beginners, in Hungary career beginners are defined as those aged 15-24 who completed secondary education at the most, as well as aged 15-29 either possessing university or college degrees, or those whose advanced studies have been interrupted. There is no consensus on the precise dates for when Generation $\mathrm{Y}$ starts and ends. Although there can be huge differences between generational characteristics, there is no clear dividing line between the age cohorts. While the generational characteristics of the Boomers and Gen X show sharp differences, Gen $\mathrm{Y}$ and $\mathrm{Z}$ are very similar: the main difference between them derives from a higher level of internet addiction and a different lifestyle due to the everyday use of electronic devices by Gen Z. Some researchers define Gen Y as the demographic cohort born in or after 1980 (Sheahan 2009), while others specify it as those born in or after 1977 (Kim et al. 2009). The cohort analysis is interesting from two aspects. On the one hand, it is known that job satisfaction or the frequency of job changes depends on age (Spector 1997, Rhodes 1983). On the other hand, if we agree that most members of Gen Y were just over 18 in 2013 (born in 1995 at the latest), we can see that most members of this generation are defined as career beginners. In other words, nowadays the overwhelming majority of career beginners belong to Gen Y. Thus, it could be interesting to analyze such factors as job search and integration problems and also other organizational variables in relation to the characteristics of other generations.

The second group of employees we analyzed is the group of teleworkers. Besides the loyalty and outstanding performance of other employees, it is also important to improve the commitment of remotely-employed workers, e.g. teleworkers who are involved in alternative work arrangements. Nowadays teleworking is still typical mostly for knowledge workers; compared to the EU-27 average, Hungary significantly lags behind in the field of teleworking as a type of employment (Makó et al. 2008). According to Makó et al. (2008) in relation to the duration of education, the ratio of teleworking for typical types of employment is increasing. However, teleworking is a flexible type of employment which provides several advantages for both the employer and the employee, e.g. more efficient work organization and the work itself, keeping the balance of professional and private lives, competitive advantages in the labour market, satisfied employees, etc., the disadvantages also must be considered, e.g. decreasing confidence among employees and decreasing allowances (Takács 2010). Teleworking is considered as a form of employment that is suited to life situations and individual career stages because an employee can control 
his/her working time, which also has both advantages and disadvantages. The essential trait of telework is a horizontal career path, mainly due to the stronger affection for the professional field, and giving preference to the aspects of self-realization. The value of human capital does not depend on the form of employment, hence it must be pointed out that the retention, satisfaction and motivation of this group is as important as that of typical workers. If attitudes towards their work and their employers are known, it is easier to typify incentive strategies which promote these objectives.

The third group is the group of re-employed. The reintegration of the unemployed into the labour market is a challenge for both employees and employers. The psychological side-effects of unemployment also depend on personality and individual differences. It has been demonstrated, for instance, that the negative consequences of unemployment are greater for those who have a high level of organizational commitment (Jackson et al. 1983) and who create high expectations in the job searching process (Frese 1987). According to research on this topic, the period which creates the negative effects of unemployment on attitudes-to-work, life-situation and well-being is about 6 months (Creed et al. 1998). Creed et al. (2009) demonstrated the correlations between distress and commitment to the job search process in relation to the duration of being unemployed. There have been several studies on the social psychological effects of unemployment on the long-term unemployed in Hungary as well (e.g. Csoba 2009, Farkas 2011). In accordance with the current legal provisions of Hungary, long-term unemployment is defined as the duration of registered unemployment of at least 12 months. The long-term unemployed must bear stress caused by lack of employment, and while maintaining their professional integrity they must rebuild their identities and visions. Despite these factors making integration more difficult, the long-term unemployed may be worth investing in.

\subsection{The effects of age and types of employment}

Regarding the generation cohorts we defined the effect of age on the organizational variables, while regarding the type of employment we analyzed the differences between the commitments of part-time and full-time workers. Part-time workers are typically women, young people as trainees, and pensioners or retired employees, resulting in huge differences in the age cohort (Conway and Briner 2002). Despite this fact, part-time workers are demonstrably different from full-time workers in the aspect of some organizational behaviour such as work status or the organizational 
environment (McGinnis and Morrow 1990), job features (Eberhardt and Shani 1984) or the degree of involvement (Wetzel et al. 1990). There are several studies on the commitment of part-time workers compared to fulltime workers. According to some researchers, the level of organizational commitment is higher for part-time workers, others say that it is higher for full-time workers, while others again say that from this viewpoint there is no difference between the two groups (Conway and Briner 2002). The reason for the contradiction above can be the avoidance of the psychological contract while explaining the research results. According to Conway and Briner (2002), the individual's psychological contract is influenced by both individual and organizational features, thus we can receive more dependable results if we analyze changes of part-time and full-time workers' commitment through selected groups of employees. The degree of commitment is influenced by the duration of time spent at work and also the nature of social interactions at work, but in the present study we do not analyze them.

We analyzed the influence of age as a team-building criteria in relation to certain generational cohorts. In the part regarding the selected groups of employees we have already introduced the most specific characteristics of Gen Y. The Boomers (1946-1964) are defined as being careerists having a strong working morale, and the opportunity for personal improvement and work status are the most important motivational factors for them (Kupperschmidt 2000). Members of Generation X (1965-1979) can find the balance of the professional and the private lives easier, most of them have higher qualifications and climbing the work hierarchy is less motivational for them (Kupperschmidt 2000). However, members of Gen Y accept the internal hierarchy rules, and they can keep up with technological innovations easier as they are also performance-oriented people who consider the role of education important and who are even more mobile than previous generations (Eisner 2005).

\subsection{Hypotheses}

According to North American researchers, there is a positive correlation indicated between affective and normative commitment (Meyer et al. 2002). When applying our questionnaire including eight items in each commitment dimension, it was found that between the two factors the value of the correlation coefficient was 0.54 . This value is also predictable in Hungary, irrespective of the groups of employees. In the research by Meyer et al. (2002), continuance commitment did not indicate a measured correlation with the 
affective and normative commitments (the correlation coefficients are 0.05 and 0.18).Furthermore, besides several other organizational factors, they also analyzed the professional commitment factor and they found it in positive correlation with the affective commitment factor (the value of the correlation coefficient is 0.52 in North America and 0.48 outside North America).

H1. In the employee commitment model, among the five commitment factors the correlation to one another is irrespective of the group of employees, thus there must be similar correlations in each group of employees.

Regarding the effect of the type of employment (e.g. part-time or fulltime employment) on the commitment of each group of employees, we make the following assumptions. Part-time teleworkers are likely to have one or more part-time jobs, thus they are likely to take the profitability of other alternative employment possibilities into lesser consideration, or they do not have other jobs, and besides their current one they can manage and keep the balance of their professional and private lives easier, thus for them the level of continuance commitment can be lower. For similar reasons we also presume that the level of professional commitment for part-time workers is also lower, because they show higher engagement in their private lives than in their professional results. Career beginners of Gen Y typically work during their studies and they are strongly motivated by performance orientation (Eisner 2005) or they are trainees on probation struggling to be the best professionals in their fields, thus their professional commitment can be higher than when they are part-time workers. Additionally, we must consider the fact that, having no other choice, deliberately committed employees do not want to lose their jobs either way, thus irrespective of this factor, regarding the other four commitment dimensions we presume that the levels of commitment are lower for the part-time employed. We consider this statement of ours valid for the reference group irrespective of any selected groups of employees.

H2A. Levels of continuance and professional commitments are lower for part-time teleworkers than full-time teleworkers.

H2B. For the career beginners of Gen $Y$ the level of professional commitment is higher for part-time workers than for full-time workers of the same generation.

H2C. For members of the reference group (who are not involved in any selected groups of employees) the levels of the affective, the normative and the continuance commitments are also lower for parttime workers than for full-time workers. 
Regarding the effect of age on commitment, we consider that in the selected groups of employees comparing the generations we do not find different results in the commitment factors. Certainly, analysis of the commitment factors in relation to the age cohorts of the career beginners of $\mathrm{Gen} \mathrm{Y}$ is meaningless. In relation to the reference group, from the aspect of generation cohorts we presume that the level of continuance commitment is lower for the younger cohorts, hence for the members of Gen Y. This can happen because they are more mobile and, regarding their relatively shorter duration of employment, such allowances have not been provided for them yet (e.g. relationships, high benefit system etc.) that would increase the perceptible expenditure of a job change.

H3. Regarding the reference group (who are not involved in any selected groups of employees) the level of the continuance commitment of Gen $Y$ is lower than that of Gen X and even that of the Boomers.

\section{METHOD}

\subsection{Sample}

We applied a questionnaire survey which allowed us to use quantitative methods. Our study was based on the commitment factors of 661 respondents including 138 career beginners from Gen Y, 99 teleworkers and 178 re-employed, thus 246 respondents belonged to the reference group (who are not involved in any selected groups of employees). The group of career beginners of Gen Y could include any person who was born between 1980 and 1995 and is employed. The group of teleworkers included employees who work flexible working hours outside of the site of the employing organization - typically at home or in telework centres by using computers and telecommunication tools on their own. The group of reemployed people includes employees who were unemployed before their current jobs for at least 6 months. During data collection we used both electronic means and personal interviews and we applied snowball sampling for 60 days in the summer of 2012. Initially, the printed and electronic questionnaires were delivered on an acquaintance basis and social networking sites, and then it was conducted by references and the secondforwarded questionnaires, and also by targeted personal surveys. We tried to ensure the sampling representativeness with doing research in the capital of Hungary, in two other major cities, some villages, and in four counties apart 
from each other geographically. 53\% of respondents are male (350 persons), and $47 \%$ are women (311 persons). In the research we endeavoured to ensure the heterogeneity of the multitude in respect of place of residence, gender and other characteristics as much as possible.

\subsection{Measures}

We evaluated only those questionnaires in which all items of all dimensions were rated by the respondents. Each dimension contained eight items. The items we applied to measure the degree of the affective (AC), continuance (CC) and normative (NC) commitment factors were based on questionnaires by Allen and Meyer (1990), and Meyer et al. (2002), while the items we applied to measure the degree of professional commitment were based on questionnaires by Aranya et al. (1981) and Rothwell and Arnold (2007). The items of deliberate commitment factor (DC) (Table 1) were created by us. We used reverse-scored items and also the 7-point Likert scales (1 to 7) in all commitment dimensions. Questionnaires have been statistically analyzed with Minitab 16.2.1. The questionnaire applied has been proved to be dependable in respect of all employees. The values for Cronbach's Alpha are: AC: 0.7065; CC: 0.7109; NC: 0.7045; PC: 0.8229; DC: 0.7191 .

Table 1

Deliberate commitment scale

\begin{tabular}{l}
\hline Deliberate Commitment Scale (1: "strongly disagree"; 7: "strongly agree”) \\
\hline 1. People who can feign loyalty will succeed at work. \\
2. In a crisis situation, it is worthwhile to show higher commitment at work than what \\
we actually feel. \\
3. There were cases when I had to show greater enthusiasm for my work than what I was \\
actually feeling, for my own interest. \\
4. I would be able to fake my attitude if I could reduce the risk of losing my job by doing \\
so. \\
5. I could never even temporarily fake my job attitude, even if I could benefit from such \\
an action. (R) \\
6. I am not considering the idea of changing jobs as I cannot see any alternative to my \\
7. Showing your true feelings at work is to be preferred over rational behaviour at all \\
times. (R)
\end{tabular}

Source: own compilation

$\mathrm{R}$ - reverse items 
The ternary structure of our presentation of the results is based upon our three main goals. First we analyzed the correlations among the commitment factors in the groups of employment and also in the reference group. Then, in each group of employees we analyzed the effects of the type of employment on the degree of the commitment factors, and finally we analyzed the same factors in relation to age cohorts (generations). The first analysis contained the sum scores of the respondents in each dimension regarding the scales of the reverse-scored items as well - then we determined the correlation coefficients among the sum scores. In the other two analyzes we examined the differences of the commitment levels in the selected groups of employees in relation to grouping criteria such as the employment type or employees' generation. Based on the Anderson-Darling normality tests, we concluded that our data, that is the sums of commitment scores are not normally distributed, the medians were used to characterize the different sub-populations and non-parametric statistical tests such as Mann-Whitney's and Mood's tests were applied to compare the examined medians. We analyzed whether forms of employment (part-time or full-time) cause significant differences in the factors' mean values in relation to all the five factors (affective, continuance, normative, professional, and deliberate) in all four tested categories of workers (career beginners of Gen Y, reemployed, telecommuters, and the reference group). The medians were applied as measures of central tendency and the Mann-Whitney test and Mood's median test were used to test the equality of medians.

\section{RESULTS}

\subsection{Determination of correlations among the commitment factors in each group of employment}

The correlations among the commitment factors are shown in Table 2. In the matrix, two values belong to each commitment factor. The upper value is the correlation coefficient and the lower is the p-value of the test in which the null hypothesis is that the correlation coefficient is equal to 0 , and the alternative hypothesis is that the correlation coefficient is not 0 . According to the correlation coefficient matrix for the career beginners of Gen Y, between the continuance-affective, the normative-affective, the professionalaffective, and the professional-normative commitment factors, there are weak positive correlations (stochastic correlations) reflected. For teleworkers 
there is a weak negative correlation between the deliberate-normative commitment factors, while for the re-employed there is also a weak negative correlation between the deliberate-affective commitment factors; there is a modest positive correlation between the professional-affective commitment factors and there are weak positive correlations between the professionalnormative and the deliberate-continuance commitment factors. As for the other relations in the selected groups of employees, according to p-values at a significance level of 0.05 (i.e. 5\%) the value of the correlation coefficient is considered 0 , thus the other commitment factor pairs are considered not to be in correlation.

According to our results for the reference group there are modest positive correlations between the normative-affective, the professional-affective and the professional-normative commitment factors, furthermore there are weak positive correlations between the continuance-affective and the normativecontinuance commitment factors, we found weak negative correlations between the deliberate-affective, the deliberate-normative and the deliberateprofessional commitment factors. As for the correlations between the professional-continuance and the deliberate-continuance commitment factors in the reference group, according to p-values at a significance level of 0.05 (i.e. $5 \%$ ) the value of the correlation coefficient is considered to be 0 .

Table 2

Correlation coefficients between individual commitment factors and the p value (in brackets) for the test that the correlation coefficient is zero vs. it is non-zero.

\begin{tabular}{lrrrr}
\hline & Affective & Continuance & Normative & Professional \\
\hline \multicolumn{5}{c}{ Generation Y individuals in their first jobs } \\
\hline Continuance & 0.172 & & & \\
Normative & $(0.044)$ & & & \\
& 0.388 & 0.090 & & \\
Professional & $(0.000)$ & $(0.293)$ & & \\
& 0.305 & 0.045 & 0.327 & \\
Deliberate & $(0.000)$ & $(0.596)$ & $(0.000)$ & -0.165 \\
& -0.038 & -0.132 & -0.100 & \\
& $(0.335)$ & $(0.123)$ & $(0.243)$ & $(0.053)$ \\
\hline Continuance & -0.120 & Teleworkers & & \\
& $(0.238)$ & & & \\
Normative & -0.093 & 0.123 & & \\
& $(0.359)$ & $(0.227)$ & & \\
Professional & 0.187 & -0.080 & 0.164 & \\
& $(0.063)$ & $(0.433)$ & $(0.105)$ & \\
Deliberate & 0.142 & 0.026 & -0.232 & -0.099 \\
& $(0.161)$ & $(0.799)$ & $(0.021)$ & $(0.328)$ \\
\hline
\end{tabular}




\begin{tabular}{|c|c|c|c|c|}
\hline \multicolumn{5}{|c|}{ The re-employed (the previously unemployed) } \\
\hline Continuance & $\begin{array}{r}0.012 \\
(0.870)\end{array}$ & & & \\
\hline Normative & $\begin{array}{r}0.144 \\
(0.056)\end{array}$ & $\begin{array}{r}0.082 \\
(0.277)\end{array}$ & & \\
\hline Professional & $\begin{array}{r}0.680 \\
(0.000)\end{array}$ & $\begin{array}{r}-0.002 \\
(0.975)\end{array}$ & $\begin{array}{r}0.207 \\
(0.006)\end{array}$ & \\
\hline Deliberate & $\begin{array}{r}-0.158 \\
(0.035) \\
\end{array}$ & $\begin{array}{r}0.151 \\
(0.044)\end{array}$ & $\begin{array}{r}-0.046 \\
(0.543) \\
\end{array}$ & $\begin{array}{r}-0.146 \\
(0.052) \\
\end{array}$ \\
\hline \multicolumn{5}{|c|}{ Reference group } \\
\hline Continuance & $\begin{array}{r}0.167 \\
(0.009)\end{array}$ & & & \\
\hline Normative & $\begin{array}{r}0.593 \\
(0.000)\end{array}$ & $\begin{array}{r}0.143 \\
(0.025)\end{array}$ & & \\
\hline Professional & $\begin{array}{r}0.522 \\
(0.000)\end{array}$ & $\begin{array}{r}0.063 \\
(0.323)\end{array}$ & $\begin{array}{r}0.522 \\
(0.000)\end{array}$ & \\
\hline Deliberate & $\begin{array}{r}-0.181 \\
(0.004)\end{array}$ & $\begin{array}{c}-0.051 \\
(0.427)\end{array}$ & $\begin{array}{c}-0.154 \\
(0.016)\end{array}$ & $\begin{array}{r}-0.189 \\
(0.003)\end{array}$ \\
\hline
\end{tabular}

Source: own calculations

\subsection{The effect of employment-type classification on the commitment factors}

We executed the Mann-Whitney tests to check how the employment type impacts the medians of commitment factors in each of the four groups of employees. The employment in our samples was either part-time or fulltime. The sample medians, the null hypotheses, alternative hypotheses, and the p-values of the conducted Mann-Whitney tests are summarized in Appendix 1.

\subsubsection{Career beginners of Generation $Y$}

At a significance level of 0.05 , we can conclude that the employment type impacts the median of professional commitment score significantly, while the employment type does not impact significantly the medians of the rest of the commitment scores. At a significance level of 0.05 , it can be accepted that the median of professional commitment score is greater for part-time employees than for the full-time ones.

\subsubsection{Teleworkers}

For teleworkers we found significant differences between the commitment score medians of part and full-time employees for two 
commitment factors. In the case of continuance and deliberate commitments, at a significance level of 0.05 we can accept that the median of the commitment score for part-time workers is less than for full-time workers. For the rest of the commitment dimensions, the employment type cannot be considered a significant differentiating factor.

\subsubsection{Re-employed employees}

In the group of re-employed employees, at a significance level of 0.05, we can accept the hypothesis that the median of employee commitment score is equal for part-time and full-time workers for each of the studied commitment factors.

\subsubsection{The reference group}

At a significance level of 0.05 , it can be accepted that the median of commitment score is less for part-time workers than for full-time employees in cases of the affective, continuance and professional commitment factors. At the same level of significance, we can also draw the conclusion that the median of the commitment score is greater for part-time workers than for full-time employees for normative commitment, while the employment type has no significant impact on the level of deliberate commitment.

\subsection{The effect of classification by age on the commitment factors}

In our sample, one of the following age categories assigned to each employee: born between 1946 and 1964, born between 1965 and 1979, and born between 1980 and 1995. Our purpose was to examine whether the employees' age - represented by the age category - has a significant influence on the commitment factors in each group of employees. In other words, we studied if the age category can be considered as a significant grouping factor. The examinations were executed by Mood's median test based on the medians of the sum scores of the commitment components. The null hypothesis for each commitment factor in each employee group was that the medians of commitment scores are the same in each age category. This means that we tested if the commitment score medians are independent from the age category. The results of Mood's median tests are summarized in Appendix 2. 


\subsubsection{Career beginners of Generation $Y$}

As the career beginners of Generation Y were all born between 1980 and 1995 , the effect of age category was not analyzed for this group.

\subsubsection{Teleworkers}

Based on the test results, at a significance level of 0.05 , there was no significant difference found in the medians of commitment scores for any of the studied commitment factors. This means that the age of teleworker employees cannot be considered as a significant grouping factor in any commitment dimension.

\subsubsection{Re-employed employees}

At a significance level of 0.05 , for each commitment factor, we can accept the hypothesis that the employee's age does not impact significantly on the median of commitment score.

\subsubsection{The reference group}

From the test results, at a significance level of 0.05 , we can conclude that the employees' age is a significant factor in the case of the continuance and professional commitment factors, while the employees' age does not impact significantly on the level of rest of the commitment factors.

The confidence intervals for the medians of continuance commitment scores in the different age categories shown below indicate that the continuance commitment level in the group of employees born between 1980 and 1995 is less than in the other employees' groups (Figure 1).

Born

$1946-1964$

$1965-1979$

$1980-1995$

Individual 95.0\% Confidence intervals

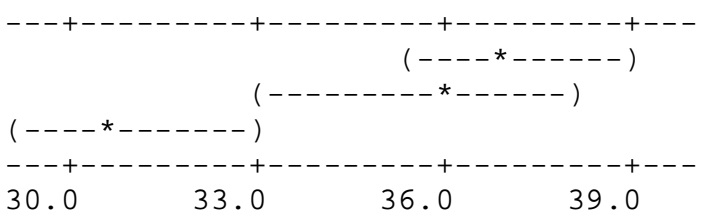

Figure 1. Confidence intervals for medians of continuance commitment scores

Source: own calculations 
From the confidence intervals in Figure 2, we can see that the employees born between 1980 and 1995 have a lower professional commitment level than the other employees.

Born

$1946-1964$

$1965-1979$

1980-1995
Individual 95.๑\% Confidence intervals

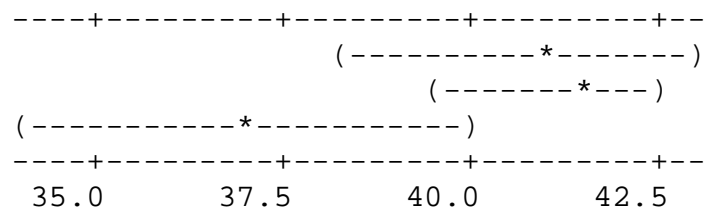

Figure 2. Confidence intervals for medians of professional commitment scores

Source: own calculations

The fact that there is a lower degree of professional commitment in the reference group of gen $\mathrm{Y}$ (i.e. who are non-career beginners at the same time) than in the group of older generations requires a specific explanation. This may be explained by frustration after their first active presence in the labour market which means that the placement in their first jobs is often not in accordance with the qualifications or the studied professions, but related to the limited achievable options. However, this pressure may make attractive other professions that are being learnt primarily in the practice of working, and perhaps this is the reason for the rate of the professional commitment is also relatively quite high in older generations.

\section{CONCLUSIONS}

Our first hypothesis $\mathrm{H} 1$ was that among the five commitment factors the correlations to one another is irrespective of the type of employment, thus we find similar correlations in each group of employees. According to Table 2 and to the section "Determination of correlations among the commitment factors in each groups of employment”, H1 cannot be accepted, thus the correlations among the commitment factors are influenced by the selected groups of employees in which the respondents are involved. The reason for this is the different commitment panels (i.e. the order of factor strength) in the groups of employees. Powell and Meyer (2004) also analyzed the correlations among the three components of the organizational commitment. They considered the correlation coefficient statistically significant above 
$0.14(\mathrm{p}=0.05)$ and above $0.19(\mathrm{p}=0.01)$. According to this, they found a modest positive correlation between AC and NC (value of correlation coefficient is 0.50) and a weak positive correlation between CC and NC (value of correlation coefficient is 0.18 ) and found no correlation between AC and CC (value of correlation coefficient is 0.09). We found similar results in the reference group in our analysis: the correlation coefficient between AC and NC is 0.59, and the correlation coefficient between CC and NC is 0.14 which actually is the same as Powell and Meyer's results (2004). There is a difference only between AC and CC where we found a weak positive correlation with a correlation coefficient of 0.16 (Table 2). Secondary pieces of information for the correlation of AC and CC factors are not equal in all cases, for instance in the analysis by Kiss et al. (2012) the correlation coefficient of this relationship was 0.44 reflecting a strong positive correlation. Regarding the groups of employees we must emphasize the groups of teleworkers and Gen Y; for them the correlation between PC and AC factors is much weaker than in any other groups of employees. The reason for this can be the different commitment panels but we intend to demonstrate it in another study of ours.

Our next group of hypotheses, including H2A, H2B and H2C, were about the effects of part-time and full-time employment on the employee commitment factors in relation to both the selected groups of employees and the reference group. According to the results we found H2A accepted, thus for part-time teleworkers the levels of the continuance and professional commitments are lower than for full-time teleworkers. Furthermore, H2B has also been demonstrated, so we can confirm that the level of professional commitment for part-time career beginners of Gen Y is higher than for fulltime career beginners. In $\mathrm{H} 2 \mathrm{C}$ we presumed that in the reference group regarding all commitment factors excluding the deliberate commitment factor, we receive lower values for part-time workers than for full-time workers. This was demonstrated for the affective, continuance and professional commitments but not for normative commitment, thus the original $\mathrm{H} 2 \mathrm{C}$ is not accepted.

Out third hypothesis H3, related to the third part of our analysis structure, was about the influence of age (i.e. the generational effect) on the commitment factors. In our sample there were 60 respondents belonging to Gen Y according to their ages but were not career beginners. According to the results in the reference group the levels of both the continuance and professional commitments are lower for members of Gen $\mathrm{Y}$ than for other generations. Thus, H3 can be accepted but must be accompanied with the fact that in the 
reference group for the members of Gen $\mathrm{Y}$ the professional commitment factor is smaller than in the other generations. Regarding the other commitment components and the reference group, we found no differences among the commitment components in relation to the selected groups of employees.

Finally, we demonstrate the existence of deliberate commitment among the employee commitment components. According to Rózsa et al. (2006),the validity of a psychological dimension exists when it shows validity while applying at least two validity indicators. For us, commitment factors can be valid regarding their functions when they show both convergent and construct validities. Convergent validity is demonstrated when regarding the other commitment factors we find only weak or no correlations. Construct validity exists when a certain definition or concept is theoretically separated from other ones opening new construction dimensions without overlapping (Rózsa et al. 2006). We have already demonstrated construct validity in the section entitled "Integration of the deliberate commitment factor with professional and organizational commitments". Table 2 shows that in the reference group the deliberate commitment factor is only in weak negative correlation, and in the selected groups of employees it is in weak negative and in weak positive correlation with the other commitment components. According to the data presented, it is now clear that there is no overlapping in the contents between deliberate commitment and other commitment components. Thus we have demonstrated that deliberate commitment also shows convergent validity and it can be declared that the component of deliberate commitment exists and its influence on employee commitment can be measured.

\section{REFERENCES}

Allen, N. J., Meyer, J. P., The Measurement and Antecedents of Affective, Continuance, and Normative Commitment to the Organization, "Journal of Occupational Psychology”, 63, pp. 1-18, 1990.

Angle, H. L., Perry, J. L., An Empirical Assessment of Organizational Commitment and Organizational Effectiveness, “Administrative Science Quarterly”, 26, pp. 1-14, 1981.

Aranya, N., Pollock, J., Amernic, J., An Examination of Professional Commitment in Public Accounting, “Accounting, Organizations and Society”, 6, pp. 271-280, 1981.

Becker, H. S., Notes on the Concept of Commitment, "American Journal of Sociology”, 66, pp. 40-53, 1960.

Bettencourt, L. A., Gwinner, K. P., Meuter, M. L., A Comparison of Attitude, Personality, and Knowledge Predictors of Service-oriented OCBs, "Journal of Applied Psychology", 86, pp. 29-41, 2001. 
Chen, C. V., Kao, R. H., Work Values and Service-oriented Organizational Citizenship Behaviors: The Mediation of Psychological Contract and Professional Commitment: A Case of Students in Taiwan Police College, "Social Indicators Research", 107, pp. 149-169, 2012.

Conway, N., Briner, R. B., Full-time versus Part-time Employees: Understanding the Links between Work Status, The Psychological Contract, and Attitudes, "Journal of Vocational Behavior”, 61, pp. 279-301, 2002.

Creed, P. A., Hicks, R. E., Machin, M. A., Behavioural Plasticity and Mental Health Outcomes for Long-term Unemployed Attending Occupational Training Programmes, "Journal of Occupational and Organizational Psychology”, 71, pp. 171-191, 1998.

Creed, P. A., Lehmann, K., Hood, M., The Relationship between Core Self-evaluations, Employment Commitment and Well-being in the Unemployed, "Personality and Individual Differences”, 47, pp. 310-315, 2009.

Csoba, J., Akarnak-e dolgozni a munkanélküliek? A munkanélküliek munkavállalói képessége és hajlandósága [Do the Unemployed Want to Work? The Ability and Willingness of the Unemployed],“Esély”, 20, pp. 3-19, 2009.

Eberhardt, B. J., Shani, A. B., The Effects of Full-time versus Part-time Employment Status on Attitudes toward Specific Organizational Characteristics and Overall Job Satisfaction, “Academy of Management Journal”, 27, pp. 893-900, 1984.

Eisenberger, R., Huntington, R., Hutchison, S., Sowa, D., Perceived Organizational Support, “Journal of Applied Psychology”, 71, pp. 500-507, 1986.

Eisner, S., Managing Generation Y, "SAM Advanced Management Journal”, 70, pp. 4-15, 2005.

Farkas, Á., A tartós munkanélküliség szociálpszichológiája [Social Psychology of the Longterm Unemployed], Debrecen, KéppontKft, 2011.

Frese, M., Alleviating Depression in the Unemployed: Adequate Financial Support, Hope and Early Retirement, “Social Science and Medicine”, 25, pp. 213-215, 1987.

Ilieva, S., Work Attitudes in Transition: Some Implications for Management of Organizational Change in Bulgaria, “Journal for East European Management Studies”, 4, pp. 279-291, 1999.

Jackson, P. R., Stafford, E. M., Banks, M. H., Warr, P. B., Unemployment and Psychological Distress: The Moderating Role of Employment Commitment, "Journal of Applied Psychology”, 68, pp. 525-535, 1983.

Kim, H., Knight, D. K., Crutsinger, C., Generation Y Employees’ Retail Work Experience: The Mediating Effect of Job Characteristics, "Journal of Business Research", 62, pp. 548-556, 2009.

Kiss, Cs., Csillag, S., Szilas, R., Takács, S., A szervezeti elkötelezettség és a munka-család viszonyrendszer összefüggései [The Relationship between Organizational Commitment and Work-life Balance], „Vezetéstudomány”, 43, pp. 2-14, 2012.

Kozlowski, S. W. J., Hults, B. M., Joint Moderation of the Relation between Task Complexity and Job Performance for Engineers, “Journal of Applied Psychology”, 71, pp. 196-202, 1986. 
Krajcsák, Z., Alkalmazotti elkötelezettségi profilok egyes speciális munkavállalói csoportokban [Workplace Commitment Profiles in Specific Employee Groups], Doctoral (PhD) Dissertation,Budapest, Budapest University of Technology and Economics, 2014.

Kupperschmidt, B., Multigeneration Employees: Strategies for Effective Management, “Health Care Manage”, 19, pp. 65-76, 2000.

Lawrence, J., Ott, M., Bell, A., Faculty Organizational Commitment and Citizenship, "Research in Higher Education”, 53, pp. 325-352, 2012.

Makó, Cs., Illésy, M., Csizmadia, P., A munkahelyi innovációk és a termelési paradigmaváltás kapcsolata [The Relation of Work-place Innovations and the Change of Production Paradigm], “Közgazdasági Szemle”, 55, pp. 1075-1093, 2008.

Mathieu, J. E., Zajac, D. M., A Review and Meta-analysis of the Antecedents, Correlates, and Consequences of Organizational Commitment, "Psychological Bulletin", 108, pp. 171194, 1990.

McGinnis, S. K., Morrow, P. C., Job Attitudes among Full- and Part-time Employees, “Journal of Vocational Behavior”, 36, pp. 82-96, 1990.

Meyer, J. P., Allen, N. J., A Three-component Conceptualization of Organizational Commitment, “Human Resource Management Review”, 1, pp. 61-89, 1991.

Meyer, J. P., Allen, N. J., Organizational Commitment: Evidence of Career Stage Effects?, “Journal of Business Research”, 26, pp. 49-61, 1993.

Meyer, J. P., Allen, N. J., Commitment in the Workplace: Theory, Research, and Application, Thousand Oaks, California, Sage Publications, 1997.

Meyer, J. P., Stanley, D. J., Herscovitch, L., Topolnytsky, L., Affective, Continuance, and Normative Commitment to the Organization: A Meta-analysis, Correlates, and Consequences, “Journal of Vocational Behavior”, 61, pp. 20-52, 2002.

Ng, T. W. H., Feldman, D. C., Locus of Control and Organizational Embeddedness, "Journal of Occupational and Organizational Psychology”, 84, pp. 173-190, 2011.

Organ, D. W., Organizational Citizenship Behavior: The Good Soldier Syndrome, Lexington, MA, Lexington Books, 1988.

Powell, D. M., Meyer, J. P., Side-bet Theory and the Three-component Model of Organizational commitment, "Journal of Vocational Behavior”, 65, pp. 157-177, 2004.

Reichers, A. E., A Review and Reconceptualization of Organizational Commitment, “Academy of Management Review”, 10, pp. 465-476, 1985.

Rhodes, S. R., Age-related Differences in Work Attitudes and Behavior: A Review and Conceptual Analysis, "Psychological Bulletin”, 93, pp. 328-367, 1983.

Rothwell, A., Arnold, J., Self-perceived Employability: Development and Validation of a Scale, "Personnel Review”, 36, pp. 23-41, 2007.

Rózsa, S., Nagybányai Nagy, O., Oláh, A. (ed.), A pszichológiai mérés alapjai [Fundamentals of Psychological Measurement]. Bölcsész Konzorcium, Budapest 2006.

Sheahan, P., Generation Y: Thriving and Surviving with Generation Y at Work. Hardie Grant Books, New York, 2009.

Sinclair, R. R., Tucker, J. S., Cullen, J. C., Performance Differences among Four Organizational Commitment Profiles, “Journal of Applied Psychology”, 90, pp. 1280-1287, 2005. 
Sorensen, J. E., Sorensen, T. L., The Conflict of Professionals in Bureaucratic Organizations, “Administrative Science Quarterly”, 19, pp. 98-106, 1974.

Spector, P. E., Job Satisfaction: Application, Assessment, Causes and Consequences. Sage Publications, California 1997.

Takács, E., A részmunkaidős foglalkoztatás és a távmunkavégzés alkalmazásának elönyei és hátrányai [Advantages and Disadvantages of Application Part-time Working and Teleworking], “Tudásmenedzsment”, 11, pp. 83-92, 2010.

Tolentino, R. C., Organizational Commitment and Job Performance of the Academic and Administrative Personnel, "International Journal of Information Technology and Business Management”, 15, pp. 1-9, 2013.

Wallace, J. E., Organizational and Professional Commitment in Professional and Nonprofessional Organizations, “Administrative Science Quarterly”, 40, pp. 228-255, 1995.

Wetzel, K., Soloshy, D. E., Gallagher, D. G., The Work Attitudes of Full-time and Part-time Registered Nurses, “Health Care Management Review”, 15, pp. 79-85, 1990.

Received: June 2013, revised: July 2014 


\section{APPENDIX 1}

\section{Impact of employment type on medians of commitment factors}

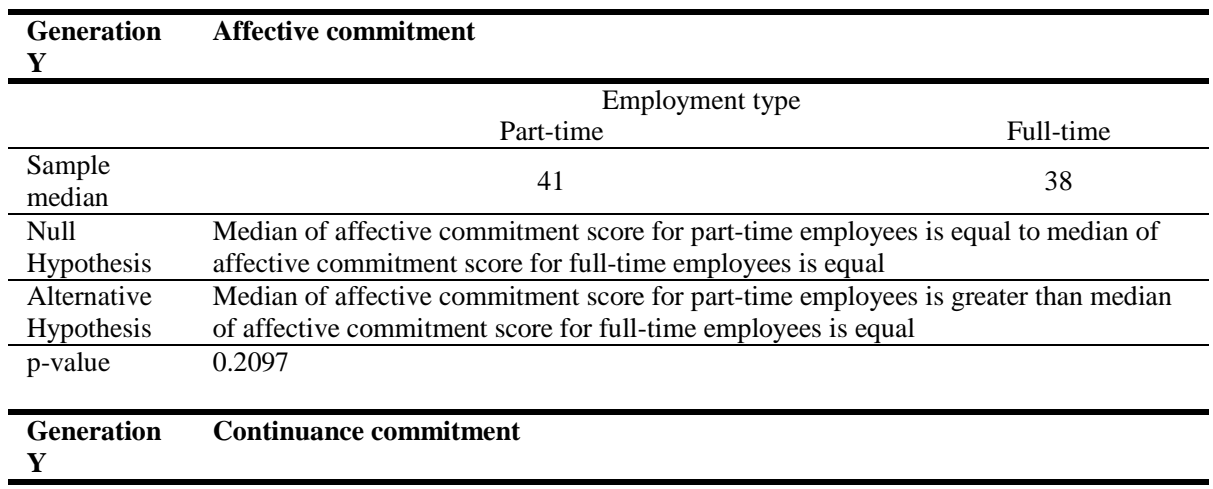

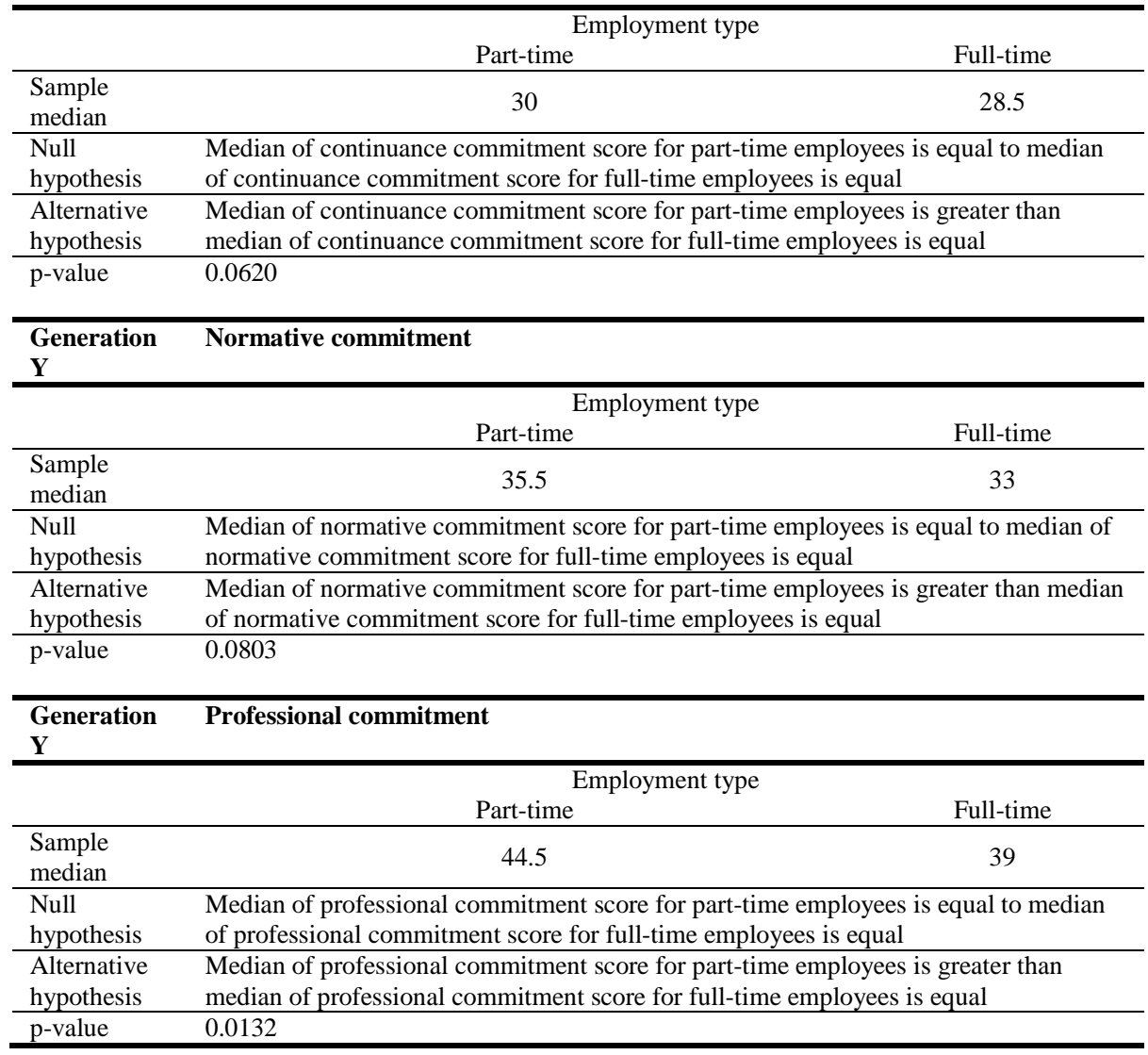




\begin{tabular}{llc}
\hline $\begin{array}{l}\text { Generation } \\
\mathbf{Y}\end{array}$ & Deliberate commitment & \multicolumn{1}{c}{ Employment type } \\
\hline \multicolumn{2}{c}{31.5} & Full-time \\
\hline $\begin{array}{l}\text { Sample } \\
\text { median }\end{array}$ & \multicolumn{2}{c}{35} \\
\hline $\begin{array}{l}\text { Null } \\
\text { hypothesis }\end{array}$ & $\begin{array}{l}\text { Median of deliberate commitment score for part-time employees is equal to median of } \\
\text { deliberate commitment score for full-time employees is equal }\end{array}$ \\
\hline $\begin{array}{l}\text { Alternative } \\
\text { hypothesis }\end{array}$ & $\begin{array}{l}\text { Median of deliberate commitment score for part-time employees is less than median of } \\
\text { deliberate commitment score for full-time employees is equal }\end{array}$ \\
\hline p-value & 0.1048 \\
\hline
\end{tabular}

\section{Teleworkers Affective commitment}

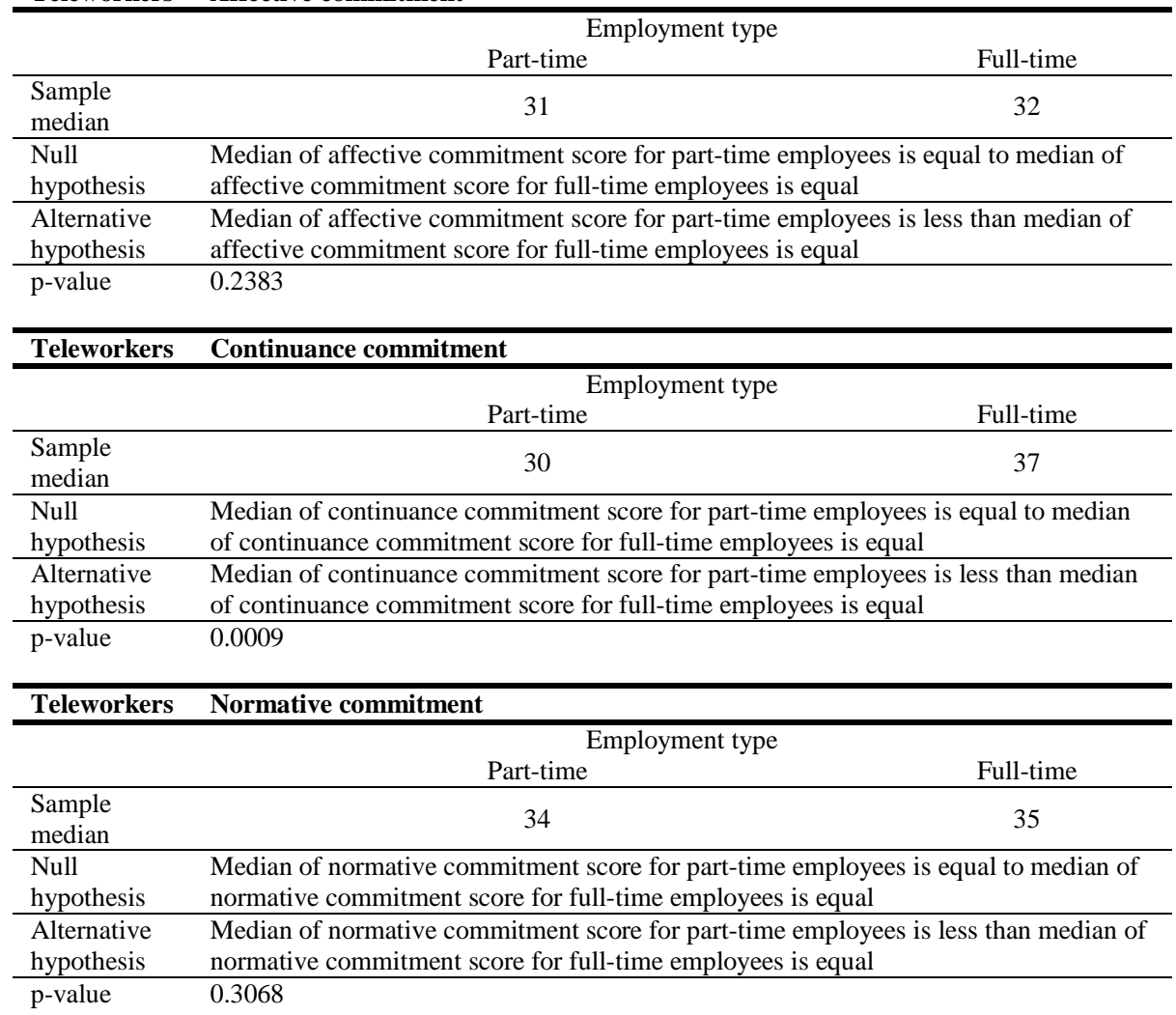




\begin{tabular}{|c|c|c|}
\hline Teleworkers & Professional commitment & \\
\hline & \multicolumn{2}{|c|}{ Employment type } \\
\hline & Part-time & Full-time \\
\hline $\begin{array}{l}\text { Sample } \\
\text { median }\end{array}$ & 32 & 34 \\
\hline $\begin{array}{l}\text { Null } \\
\text { hypothesis }\end{array}$ & \multicolumn{2}{|c|}{$\begin{array}{l}\text { Median of professional commitment score for part-time employees is equal to median } \\
\text { of professional commitment score for full-time employees is equal }\end{array}$} \\
\hline $\begin{array}{l}\text { Alternative } \\
\text { hypothesis }\end{array}$ & \multicolumn{2}{|c|}{$\begin{array}{l}\text { Median of professional commitment score for part-time employees is less than } \\
\text { median of professional commitment score for full-time employees is equal }\end{array}$} \\
\hline p-value & \multicolumn{2}{|c|}{0.0111} \\
\hline \multirow[t]{3}{*}{ Teleworkers } & \multicolumn{2}{|l|}{ Deliberate commitment } \\
\hline & \multicolumn{2}{|c|}{ Employment type } \\
\hline & Part-time & Full-time \\
\hline $\begin{array}{l}\text { Sample } \\
\text { median }\end{array}$ & 33 & 34 \\
\hline $\begin{array}{l}\text { Null } \\
\text { hypothesis }\end{array}$ & \multicolumn{2}{|c|}{$\begin{array}{l}\text { Median of deliberate commitment score for part-time employees is equal to median } \\
\text { of deliberate commitment score for full-time employees is equal }\end{array}$} \\
\hline $\begin{array}{l}\text { Alternative } \\
\text { hypothesis }\end{array}$ & \multicolumn{2}{|c|}{$\begin{array}{l}\text { Median of deliberate commitment score for part-time employees is less than median } \\
\text { of deliberate commitment score for full-time employees is equal }\end{array}$} \\
\hline p-value & \multicolumn{2}{|c|}{0.1286} \\
\hline
\end{tabular}

\begin{tabular}{|c|c|c|}
\hline \multirow[t]{3}{*}{ Re-employed } & \multicolumn{2}{|l|}{ Affective commitment } \\
\hline & \multicolumn{2}{|c|}{ Employment type } \\
\hline & Part-time & Full-time \\
\hline $\begin{array}{l}\text { Sample } \\
\text { median }\end{array}$ & 34 & 34 \\
\hline $\begin{array}{l}\text { Null } \\
\text { hypothesis }\end{array}$ & \multicolumn{2}{|c|}{$\begin{array}{l}\text { Median of affective commitment score for part-time employees is equal to median of } \\
\text { affective commitment score for full-time employees is equal }\end{array}$} \\
\hline $\begin{array}{l}\text { Alternative } \\
\text { hypothesis }\end{array}$ & \multicolumn{2}{|c|}{$\begin{array}{l}\text { Median of affective commitment score for part-time employees is not equal to } \\
\text { median of affective commitment score for full-time employees is equal }\end{array}$} \\
\hline p-value & \multicolumn{2}{|c|}{0.5987} \\
\hline \multirow[t]{3}{*}{ Re-employed } & \multicolumn{2}{|c|}{ Continuance commitment } \\
\hline & \multicolumn{2}{|c|}{ Employment type } \\
\hline & Part-time & Full-time \\
\hline $\begin{array}{l}\text { Sample } \\
\text { median }\end{array}$ & 29 & 34 \\
\hline $\begin{array}{l}\text { Null } \\
\text { hypothesis }\end{array}$ & \multicolumn{2}{|c|}{$\begin{array}{l}\text { Median of continuance commitment score for part-time employees is equal to median } \\
\text { of continuance commitment score for full-time employees is equal }\end{array}$} \\
\hline $\begin{array}{l}\text { Alternative } \\
\text { hypothesis }\end{array}$ & \multicolumn{2}{|c|}{$\begin{array}{l}\text { Median of continuance commitment score for part-time employees is less than } \\
\text { median of continuance commitment score for full-time employees is equal }\end{array}$} \\
\hline p-value & \multicolumn{2}{|c|}{0.0610} \\
\hline \multirow[t]{3}{*}{ Re-employed } & \multicolumn{2}{|l|}{ Normative commitment } \\
\hline & \multicolumn{2}{|c|}{ Employment type } \\
\hline & Part-time & Full-time \\
\hline $\begin{array}{l}\text { Sample } \\
\text { median }\end{array}$ & 37 & 38 \\
\hline $\begin{array}{l}\text { Null } \\
\text { hypothesis }\end{array}$ & \multicolumn{2}{|c|}{$\begin{array}{l}\text { Median of normative commitment score for part-time employees is equal to median } \\
\text { of normative commitment score for full-time employees is equal }\end{array}$} \\
\hline $\begin{array}{l}\text { Alternative } \\
\text { hypothesis }\end{array}$ & \multicolumn{2}{|c|}{$\begin{array}{l}\text { Median of normative commitment score for part-time employees is less than median } \\
\text { of normative commitment score for full-time employees is equal }\end{array}$} \\
\hline p-value & \multicolumn{2}{|c|}{0.1164} \\
\hline
\end{tabular}




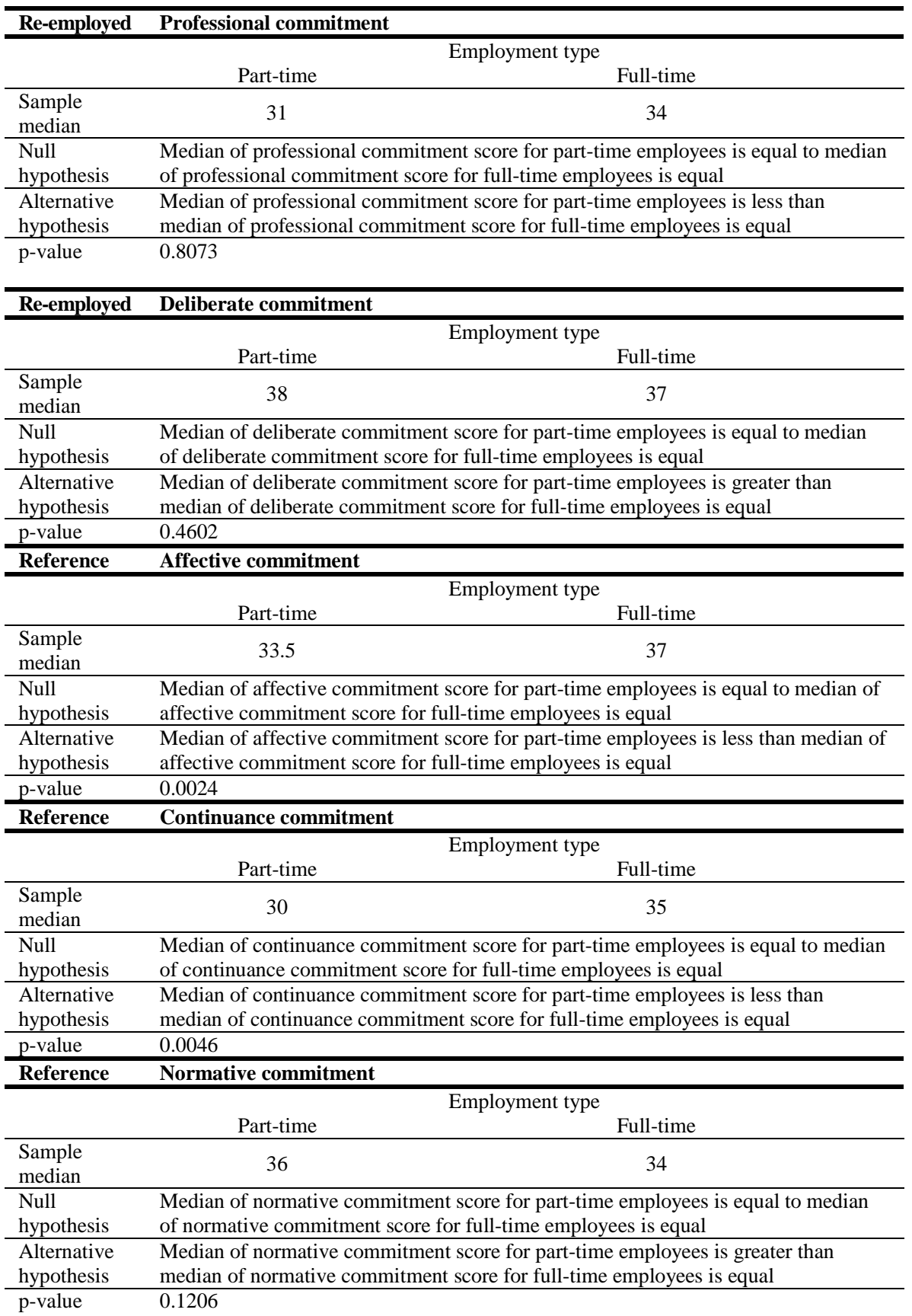




\begin{tabular}{|c|c|c|}
\hline Reference & Professional commitment & \\
\hline & \multicolumn{2}{|c|}{ Employment type } \\
\hline & Part-time & Full-time \\
\hline $\begin{array}{l}\text { Sample } \\
\text { median }\end{array}$ & 33 & 41 \\
\hline $\begin{array}{l}\text { Null } \\
\text { hypothesis }\end{array}$ & \multicolumn{2}{|c|}{$\begin{array}{l}\text { Median of professional commitment score for part-time employees is equal to median } \\
\text { of professional commitment score for full-time employees is equal }\end{array}$} \\
\hline $\begin{array}{l}\text { Alternative } \\
\text { hypothesis }\end{array}$ & \multicolumn{2}{|c|}{$\begin{array}{l}\text { Median of professional commitment score for part-time employees is less than } \\
\text { median of professional commitment score for full-time employees is equal }\end{array}$} \\
\hline p-value & \multicolumn{2}{|c|}{0.0061} \\
\hline \multirow[t]{3}{*}{ Reference } & \multicolumn{2}{|l|}{ Deliberate commitment } \\
\hline & \multicolumn{2}{|c|}{ Employment type } \\
\hline & Part-time & Full-time \\
\hline $\begin{array}{l}\text { Sample } \\
\text { median }\end{array}$ & 33 & 33 \\
\hline $\begin{array}{l}\text { Null } \\
\text { hypothesis }\end{array}$ & \multicolumn{2}{|c|}{$\begin{array}{l}\text { Median of deliberate commitment score for part-time employees is equal to median } \\
\text { of deliberate commitment score for full-time employees is equal }\end{array}$} \\
\hline $\begin{array}{l}\text { Alternative } \\
\text { hypothesis }\end{array}$ & \multicolumn{2}{|c|}{$\begin{array}{l}\text { Median of deliberate commitment score for part-time employees is not equal to } \\
\text { median of deliberate commitment score for full-time employees is equal }\end{array}$} \\
\hline p-value & \multicolumn{2}{|l|}{0.9999} \\
\hline
\end{tabular}




\section{APPENDIX 2}

\section{Impact of employees' age on medians of commitment factors}

\begin{tabular}{|c|c|c|c|}
\hline Teleworkers & Affective commitment & & \\
\hline & & Age category & \\
\hline & 1946-1964 & 1965-1979 & $1980-1990$ \\
\hline Sample median & 31 & 30 & 32 \\
\hline p-value & 0.384 & & \\
\hline \multirow[t]{3}{*}{ Teleworkers } & Continuance commitment & & \\
\hline & & Age category & \\
\hline & 1946-1964 & $1965-1979$ & $1980-1990$ \\
\hline Sample median & 34 & 35 & 37 \\
\hline p-value & 0.394 & & \\
\hline \multirow[t]{3}{*}{ Teleworkers } & Normative commitment & & \\
\hline & & Age category & \\
\hline & 1946-1964 & 1965-1979 & $1980-1990$ \\
\hline Sample median & 33 & 37 & 35 \\
\hline p-value & 0.059 & & \\
\hline \multirow[t]{3}{*}{ Teleworkers } & Professional commitment & & \\
\hline & & Age category & \\
\hline & 1946-1964 & 1965-1979 & $1980-1990$ \\
\hline Sample median & 33 & 34 & 34 \\
\hline p-value & 0.696 & & \\
\hline \multirow[t]{3}{*}{ Teleworkers } & Deliberate commitment & & \\
\hline & & Age category & \\
\hline & 1946-1964 & 1965-1979 & $1980-1990$ \\
\hline Sample median & 35 & 35 & 33 \\
\hline p-value & 0.457 & & \\
\hline \multirow[t]{3}{*}{ Re-employed } & Affective commitment & & \\
\hline & & Age category & \\
\hline & 1946-1964 & 1965-1979 & $1980-1990$ \\
\hline Sample median & 37 & 34 & 33 \\
\hline p-value & 0.164 & & \\
\hline \multirow[t]{3}{*}{ Re-employed } & Continuance commitment & & \\
\hline & & Age category & \\
\hline & 1946-1964 & 1965-1979 & $1980-1990$ \\
\hline Sample median & 37 & 31 & 34 \\
\hline p-value & 0.249 & & \\
\hline \multirow[t]{3}{*}{ Re-employed } & Normative commitment & & \\
\hline & & Age category & \\
\hline & 1946-1964 & 1965-1979 & $1980-1990$ \\
\hline Sample median & 33.5 & 37 & 35 \\
\hline
\end{tabular}




\begin{tabular}{|c|c|c|c|}
\hline Re-employed & Professional commitment & & \\
\hline & & Age category & \\
\hline & $1946-1964$ & 1965-1979 & $1980-1990$ \\
\hline Sample median & 38 & 33 & 33 \\
\hline p-value & 0.389 & & \\
\hline \multirow[t]{3}{*}{ Re-employed } & Deliberate commitment & & \\
\hline & & Age category & \\
\hline & 1946-1964 & 1965-1979 & $1980-1990$ \\
\hline Sample median & 35 & 38 & 37 \\
\hline p-value & 0.119 & & \\
\hline \multirow[t]{3}{*}{ Reference } & Affective commitment & & \\
\hline & & Age category & \\
\hline & $1946-1964$ & 1965-1979 & $1980-1990$ \\
\hline Sample median & 37 & 37 & 37 \\
\hline p-value & 0.439 & & \\
\hline \multirow[t]{3}{*}{ Reference } & Continuance commitment & & \\
\hline & & Age category & \\
\hline & 1946-1964 & 1965-1979 & $1980-1990$ \\
\hline Sample median & 37 & 36 & 30 \\
\hline p-value & 0.001 & & \\
\hline \multirow[t]{3}{*}{ Reference } & Normative commitment & & \\
\hline & & Age category & \\
\hline & $1946-1964$ & 1965-1979 & $1980-1990$ \\
\hline Sample median & 34 & 34 & 33.5 \\
\hline p-value & 0.986 & & \\
\hline \multirow[t]{3}{*}{ Reference } & Professional commitment & & \\
\hline & & Age category & \\
\hline & $1946-1964$ & 1965-1979 & $1980-1990$ \\
\hline Sample median & 41 & 42 & 37 \\
\hline p-value & 0.031 & & \\
\hline \multirow[t]{3}{*}{ Reference } & Deliberate commitment & & \\
\hline & & Age category & \\
\hline & $1946-1964$ & 1965-1979 & $1980-1990$ \\
\hline Sample median & 33 & 32 & 33 \\
\hline
\end{tabular}

